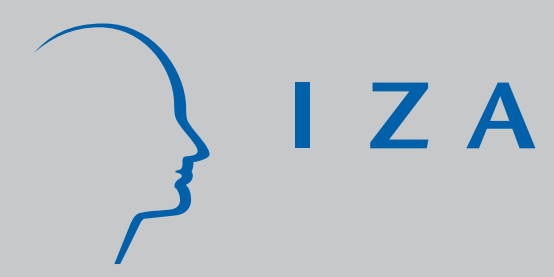

IZADP No. 3754

The Economic Impact of Immigration in Greece: Taking Stock of the Existing Evidence

Ioannis Cholezas

Panos Tsakloglou

October 2008 


\title{
The Economic Impact of Immigration in Greece: Taking Stock of the Existing Evidence
}

\author{
Ioannis Cholezas \\ University of Peloponnese and KEPE \\ Panos Tsakloglou \\ Athens University of Economics and Business, \\ IMOP and IZA
}

Discussion Paper No. 3754

October 2008

IZA

P.O. Box 7240

53072 Bonn

Germany

Phone: +49-228-3894-0

Fax: +49-228-3894-180

E-mail: iza@iza.org

Any opinions expressed here are those of the author(s) and not those of IZA. Research published in this series may include views on policy, but the institute itself takes no institutional policy positions.

The Institute for the Study of Labor (IZA) in Bonn is a local and virtual international research center and a place of communication between science, politics and business. IZA is an independent nonprofit organization supported by Deutsche Post World Net. The center is associated with the University of Bonn and offers a stimulating research environment through its international network, workshops and conferences, data service, project support, research visits and doctoral program. IZA engages in (i) original and internationally competitive research in all fields of labor economics, (ii) development of policy concepts, and (iii) dissemination of research results and concepts to the interested public.

IZA Discussion Papers often represent preliminary work and are circulated to encourage discussion. Citation of such a paper should account for its provisional character. A revised version may be available directly from the author. 
IZA Discussion Paper No. 3754

October 2008

\section{ABSTRACT \\ The Economic Impact of Immigration in Greece: Taking Stock of the Existing Evidence ${ }^{*}$}

Greece was traditionally an emigration country. However, since the early 1990 s it became an immigrant destination and nowadays up to a tenth of the population are immigrants, mainly from neighbouring Balkan countries and, especially, Albania. This large scale immigration within a short time period had important social, as well as, economic consequences. The paper reviews the existing evidence and concludes that on average the economic effects of immigration were beneficial, although their distributional consequences were adverse. Greek immigration policy was haphazard and more efforts are needed in order to integrate the immigrants in the economic and social fabric of the country.

JEL Classification: F22

Keywords: $\quad$ immigration, Greece

Corresponding author:

Panos Tsakloglou

Department of International and European Economic Studies

Athens University of Economics and Business

76 Patission Street

Athens 10434

Greece

E-mail: panos@aueb.gr

\footnotetext{
* Research carried out in the framework of the EU-supported research project "Social impact of globalisation in Europe (SIMGLOBE)". The authors would like to thank the project coordinator lain Begg as well as Jenifer Cavounidis, Ruby Gropas, Kostas Kanellopoulos, Theodore Lianos and Anna Triandafyllidou for useful comments and suggestions.
} 


\section{Introduction}

Migration is considered by many social scientists as one of the most important phenomena of our time. Apart from the direct consequences on the size and structure of a country's population, both for the origin and the host country, there are numerous other effects of migration, either positive or negative, in the short-run or in the long-run, that need to be carefully investigated. For example, migration flows seem to affect directly each economy's output and unemployment rate, while they have more complex impacts on growth rates, trade relations and balance of payments, the demand for education, health services and social infrastructure, as well as, on the political, social and cultural conditions of both countries.

Ever since the creation of the modern Greek state in 1830 - in fact, far earlier than that - Greece was an emigration country. Initially, the destination of the immigrants were mainly the lands of the Ottoman Empire, Central and Eastern European countries as well as Egypt, in the first half of the twentieth century USA and after World War II Western Europe (principally West Germany) and Australia. This came to a halt with the first oil crisis. Between the mid-1970s and the late 1980s net migration was close to zero (Lianos, 1975; Venturini, 2004). The collapse of the communist regimes at the end of the 1980s caused an unprecedented influx of economic immigrants coming mainly from the former communist countries of Eastern Europe and the Soviet Union. Like other Southern European countries (Italy. Spain, Portugal), large numbers of immigrants arrived in Greece in a short period of time. ${ }^{1}$ Despite the fact that these countries have certain similarities (large informal sectors, low labour force participation rates, large agricultural and labour intensive sectors and ageing populations) that tend to favour the illegal or semi-illegal employment of immigrants, their experiences are very different. For example, Greece's immigrants come predominantly from one country (Albania) and are usually unskilled. In addition, their share in the total population is substantially higher than in the other Southern European countries, most of them entered the country illegally and, last but not least, the Greek perception of ethnicity seems to be a serious drawback in the immigrants' integration process (Cavounidis (2002a); Baldwin-Edwards, 2004a).

$1 \quad$ The experiences of these three South-European countries are considered similar. For a general discussion of migration in southern Europe see Venturini (2004). 
The fact that Greece has always been a migrant exporting country and has suddenly become a migrant importing country caught the government and the society, on the whole, off guard and raised a number of issues that ranged from dealing with xenophobia and racism to the formation of a proper migration policy. These issues have been investigated to some extend, some more than others, but the lack of appropriate statistical information poses serious problems. The purpose of this paper is to survey the existing literature on migration in Greece, by focusing on the economic effects of immigration.

\section{A Brief History of Migration in Greece}

Although, as noted above emigration was a salient feature of the modern Greek state, two major waves of mass emigration can be traced. The first goes back to the end of the $19^{\text {th }}$ and the beginning of the 20 $20^{\text {th }}$ century. It was triggered by the economic crisis of 1893 that followed the drastic fall in the price of currants internationally (currants being the main export commodity of Greece at that time). It is estimated that during the period 1890-1914 almost a sixth of Greece's population emigrated to the United States and Egypt (Kassimis \& Kassimi, 2004). Greek authorities encouraged emigration as a means of improving the balance of payments of the local economy through remittances.

The second emigration wave began a little after the end of World War II and lasted for almost twenty years, from the beginning of the 1950s up until the mid 1970s. The economic and political situation in Greece is usually considered to have played an important role in driving this second emigration wave. During that time Greece was a sender of migrants to the United States, Australia, Canada and many Western European countries (mainly West Germany, Belgium and Sweden). It is estimated that approximately 1.2 million people left Greece. Many of them returned to Greece. For example, between 1968 and 1974, 392 thousand persons left Greece, while 159 thousand persons returned (Lianos, 1975 and 1980).

The oil crises of 1973 and 1980 caused economic instability in the host countries and led to the reduction of demand for foreign labour. As a result, the industrialised countries of Northern Europe introduced more restrictive immigration policies. Immigrants, including Greek immigrant, were encouraged to return to their home 
countries, while others were discouraged from leaving their countries. Especially after 1974, when democracy was re-established in Greece following a period of military junta rule (1967-1974), the inflow of repatriating immigrants started to outnumber the outflow of emigrants. As a result, it is estimated, that between 1975 and 1977, 82 thousand people emigrated as opposed to 103 thousand people, who returned to Greece (Lianos, 1980; Katseli \& Glytsos, 1989). At the same time, flows in the opposite direction started to emerge. For example, in 1972, the Greek consulate in Cairo handed out 10,000 visas to Egyptian workers acting on the concern for labour shortages expressed by the Greek Federation of Industry (SEV) (Koniordos, 1994). Since then, the number of regular immigrants to Greece continued to rise. Unfortunately, the National Statistical Service of Greece stopped collecting data on migration flows in 1977, but according to data collected by the Ministry of Labour, there were 28,628 legally employed immigrants in Greece in 1980, 28,422 in 1990 and 33,912 in 1992 (Kirpianos et al, 2003).

The immigration flows changed drastically since the second half of the 1980s, when Greece encountered an inflow of immigrants from countries of Central and Eastern Europe resulting from the communist regimes' liberalisation process. The first migrants came from Poland and were quickly succeeded by Bulgarians and Romanians. A rising flow of immigrants followed the collapse of the Soviet Union and the former communist countries at the end of the 1980s. The inflow of migrants reached its peak at the beginning of the 1990s, when Albanians started moving into Greece. Although many immigrants were of Greek descent (Pontic Greeks from the former Soviet Union and Greek Albanians) and were entitled to special residence and employment status, for the vast majority of immigrants this was not the case. As a result, by the mid 1990s Greece was characterised by large numbers of immigrants, often without the necessary documents ("undocumented" or "illegal") (Cavounidis, 2002a).

The sudden inflow of immigrants found Greece completely unprepared and caused haphazard attempts from the government's side to form a proper migration policy. Law 1975/1991 entitled “Entry, exit, sojourn, employment, removal of aliens, procedure for the recognition of refugees and other measures" aimed primarily at restricting immigration and facilitating the removal of illegal immigrants and other foreigners temporarily residing in Greece. With a considerable delay, Greece 
implemented the first regularisation program in $1998^{2}$, following the issuance of two presidential decrees, which were implemented in two successive stages. In the first stage, a "Temporary Residence Permit Card" was issued, known as the "white card", while the second stage involved the issuance of a limited duration residence card, known as the "green card". In order to be eligible to apply for the "green card", an immigrant ought to prove that he/she was legally employed for a minimum of forty days since January $1^{\text {st }} 1998$, which is usually considered a decisive factor affecting the program's success (Cavounidis, 2002a and 2002b). The second regularisation program was introduced -before the completion of the first one- by law 2910/2001 entitled "Entry and sojourn of foreigners in the Greek territory, naturalisation and other measures" in 2001 aiming primarily at attracting those who did not participate in the first one. Due to the fact that the permit was initially issued for only one year, thus causing serious problems to both the authorities and the immigrants who were incurring costs in terms of money and time, the process was revised in January 2004 (Act 3202/2003) to provide for a two-year permit and, thus, facilitate the procedure.

The next step was a three year action plan introduced in 2001 entitled "Action Plan for the Social Integration of Immigrants (for the period 2002-2005)", which included measures attempting to help immigrants' integration into the Greek labour market, ensure their access to health services, promote cultural interaction and fight xenophobia and racism within the Greek society, but it was outshined by the 2004 Olympic Games. The most recent attempt to deal with immigration took place in August 2005, when a new immigration law (3386/2005) was approved by the Greek Parliament entitled "Entry, stay and integration of third country nationals in Greece" (Triandafyllidou, 2005). Critics of this bill point out that it continued to ignore almost $70 \%$ of undocumented immigrants in Greece by not allowing them to obtain residence permits (Gropas \& Triandafyllidou, 2005a). On the other hand, one must accept the fact that the repetitive nature of the regularisation processes indicated a more pragmatic approach adopted by the authorities towards immigration. Furthermore, it helped the majority of immigrants to ensure a certain degree of dignity within the Greek society and facilitated many practical aspects of their lives in Greece (Hatziprokopiou, 2005).

2 By the time Greece implemented its first regularisation program, Italy was undertaking its fourth program, while Spain had already implemented three programs and Portugal two (OECD, 1999a). 
In general, it can be argued that the Greek migration policy, through the aforementioned pieces of legislation, seems to lack social justification in the sense that it does not provide for the actual integration of immigrants into the Greek society (social security and social and human rights). ${ }^{3}$ Nevertheless, the initiatives of non-state actors, such as community associations, left-wing parties, NGOs, antiracist groups, trade unions, the church etc. have partly substituted for the paucity of state's actions aiming at supporting immigrants and protecting their rights (Hatziprokopiou, 2005). A considerable proportion of immigrants are still not entitled to social security benefits, they are not eligible for unemployment benefits, their wages are lower, sometimes considerably so, in comparison with those determined by collective bargaining and they face difficulties in family reunification (Robolis, 2005; Kapsalis, 2005; Kapsalis \& Linardos-Rylmon, 2005). Hence, the main challenge facing Greek migration policy is twofold; first, how to effectively control migrant inflows and, second, to prevent legal immigrants from lapsing into illegality and help promote their economic and social integration ${ }^{4}$ (Fakiolas, 2003; Simopoulos, 2005).

\section{A profile of the immigrant population}

There are few data sets providing reliable quantitative information for the empirical study of aspects of immigration in Greece and they are mainly collected by state agencies, such as the National Statistical Service of Greece (ESYE), the Ministry of Labour, the Ministry of Education and Religion Affairs, the Ministry of Foreign Affairs, the Ministry of Public Order, the Ministry of Internal Affairs and the Institution for Social Security (IKA). The first nationwide dataset came from the first

3 Further, it should be noted that Greece signed a number of bilateral agreements with neighbouring countries aiming at controlling illegal immigration and regulating the Greek labour market by focusing on seasonal employment. At the beginning of the 1990s such an agreement was signed with Albania in order to issue 30,000 seasonal work permits. In 1995 a cooperation treaty with Bulgaria was signed, which provided for three-month work permits for Bulgarian citizens who wished to work in Greece. Finally, in May 1996 a treaty was signed with Albania, which was validated by Law 2482/1997 and was setting the rules for accepting seasonal workers from Albania to Greece (Bagavos \& Papadopoulou, 2002).

$4 \quad$ Education policies aimed at promoting immigrants' integration are not discussed in detail here. Nevertheless, such policies are clearly very important in the long run since education plays a crucial role, on the one hand, in determining identity formation, national cohesion and national consciousness and, on the other hand, in determining access to the labour market, personal and economic development. For a thorough discussion of Greek education policies regarding immigrants, see Triandafyllidou \& Gropas (2007). 
regularisation program of 1998, while a more recent one is the 2001 Census carried out by ESYE. Other datasets include micro-data from the Labour Force Surveys by ESYE, unpublished data from the Labour Force Employment Organisation (OAED) and a survey conducted by the General Secretariat of Emigrant Greeks (GSEG) in 2000. The most recent source of information is the 2004/5 Household Budget Survey (HBS) carried out by ESYE. Furthermore, some researchers have resorted to collecting data themselves, by conducting their own surveys, limited to small nonrandom samples (often less than 150 observations). Undoubtedly, their results should be interpreted with utmost caution. Most importantly, the majority of these datasets do no collect information on income, which is a sine qua non, when investigating a considerable number of economic effects of immigration. ${ }^{5}$

\section{Graph 1 - The Evolution of the Immigrant Population}

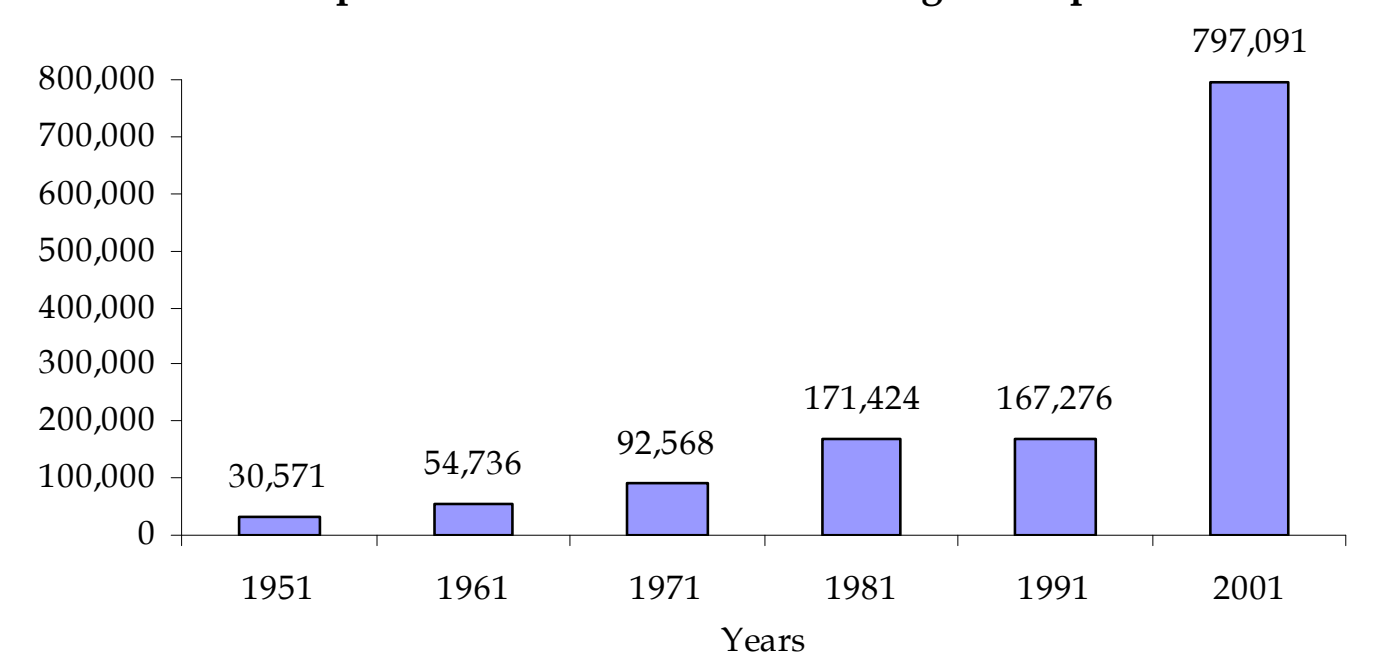

Source: National Statistical Service of Greece (ESYE)

Between 1991 and 2001 the population of Greece increased by almost 7\%, while the immigrant population - both legal and illegal (undocumented) - more than tripled to account for $7.3 \%$ of the entire population in 2001 (a total of 797,091). ${ }^{6}$

$5 \quad$ For a thorough discussion of available data sources on immigrants in Greece see Baldwin-Edwards (2004c) and Kontis et al. (2006).

$6 \quad$ According to Gropas \& Triandafyllidou (2005b) almost 30,000 immigrants reported "return to homeland" as their main reason of immigration (12,000 from Albania, 5,000 from Georgia, 5,000 from Russia, 2,500 from Turkey, 2,300 from FYROM, 1,000 from Kazakhstan) and, thus, this number is a good approximation for immigrants of Greek origin. In addition, 
Unfortunately, there are detailed demographic data for only 762,191 of them. Graph 1 shows the evolution of immigrant population in Greece between 1951 and 2001 using data from Population Censuses. The small decline between 1981 and 1991 should be attributed to the considerable proportion of undocumented immigrants who did not appear in the 1991 Census. Recent estimates that take into account undocumented immigrants raise the total number of immigrants in the early years of the $21^{\text {st }}$ century to more than a million; that is, $9 \%-10 \%$ of the population. (Gropas \& Trandafyllidou, 2005a and 2005b; Kontis et al., 2006)

The majority of immigrants came from neighbouring Balkan countries, such as Albania and Bulgaria7, probably due to geographical proximity, which shapes the pattern of migration, affects the length of stay and the frequency of trips back to the country of origin (Cavounidis, 2002a). Table 1 reports the composition of the foreign population in Greece according to the 2001 Census.

A first look at the table reveals that immigrants from Albania account for more than half of all immigrants in Greece (57.5\%). The second largest group are those from Bulgaria (4.6\%), followed by immigrants from Georgia (3.0\%), Romania $(2.9 \%)$ and Russia (2.3\%). ${ }^{8}$ Amongst the new EU member-states, Cypriots $(2.3 \%)$ and Poles $(1.7 \%)$ are the biggest groups of immigrants. There is also a considerable proportion of immigrants from developed countries, e.g. the UK (1.7\%), Germany (1.5\%), Italy $(0.8 \%)$, the US $(2.4 \%)$ and Australia (1.2\%), many of whom are likely to be of Greek descent. A comparison with the data collected during the first regularisation program (1998) does not reveal important differences regarding the composition of the immigrant population (Cavounidis, 2002b). Further, on aggregate, there are more male $(54.5 \%)$ than female immigrants, but the composition varies widely among different nationalities, probably due to cultural differences (Gropas \& Triandafyllidou, 2005a; Hatziprokopiou, 2005; Cavounidis, 2002a and 2002b).

approximately 100,000 Greek-Albanians (Vorioepirotes) have been granted Greek citizenship and, thus, were not considered foreigners in the 2001 Census.

$7 \quad$ For a detailed discussion of immigrants' characteristics with special reference to three Balkan countries (Albania, Bulgaria and Romania) see Cavounidis (2004). The author reviews immigrants' gender, age, marital status, family composition, reasons for coming to Greece and, in particular, employment, remittance behaviour and intended length of stay and she finds significant differences across the three ethnic groups.

$8 \quad$ Based on residence permits data, Kontis et al. (2006) report higher percentages of Albanians (63.2\%), Bulgarians (9.8\%), Romanians (4.3\%) and Ukrainians (3.4\%) among immigrants in 2003/4. 
Table 1 - Foreign population in Greece (2001 Census)

\begin{tabular}{lrrrr}
\hline & \multicolumn{1}{c}{ All } & \% of Total & Females & $\%$ of All \\
\hline Albania & 438,036 & $57.5 \%$ & 180,887 & $41.3 \%$ \\
Bulgaria & 35,104 & $4.6 \%$ & 21,216 & $60.4 \%$ \\
Georgia & 22,875 & $3.0 \%$ & 13,036 & $57.0 \%$ \\
Romania & 21,994 & $2.9 \%$ & 9,547 & $43.4 \%$ \\
US & 18,140 & $2.4 \%$ & 9,335 & $51.5 \%$ \\
Russia & 17,535 & $2.3 \%$ & 10,990 & $62.7 \%$ \\
Cyprus & 17,426 & $2.3 \%$ & 9,142 & $52.5 \%$ \\
Ukraine & 13,616 & $1.8 \%$ & 10,274 & $75.5 \%$ \\
UK & 13,196 & $1.7 \%$ & 7,927 & $60.1 \%$ \\
Poland & 12,831 & $1.7 \%$ & 6,955 & $54.2 \%$ \\
Germany & 11,806 & $1.5 \%$ & 7,060 & $59.8 \%$ \\
Pakistan & 11,130 & $1.5 \%$ & 476 & $4.3 \%$ \\
Australia & 8,767 & $1.2 \%$ & 4,662 & $53.2 \%$ \\
Turkey & 7,881 & $1.0 \%$ & 3,883 & $49.3 \%$ \\
Armenia & 7,742 & $1.0 \%$ & 4,127 & $53.3 \%$ \\
Egypt & 7,448 & $1.0 \%$ & 1,775 & $23.8 \%$ \\
India & 7,216 & $0.9 \%$ & 494 & $6.8 \%$ \\
Iraq & 6,936 & $0.9 \%$ & 2,095 & $30.2 \%$ \\
Philippines & 6,478 & $0.8 \%$ & 4,949 & $76.4 \%$ \\
Canada & 6,049 & $0.8 \%$ & 3,126 & $51.7 \%$ \\
Italy & 5,825 & $0.8 \%$ & 3,068 & $52.7 \%$ \\
Syria & 5,552 & $0.7 \%$ & 1,152 & $20.7 \%$ \\
Moldova & 5,176 & $0.7 \%$ & 4,007 & $77.4 \%$ \\
Other & 53,432 & $7.0 \%$ & 26,456 & $49.5 \%$ \\
\hline Total & 762,191 & $100.0 \%$ & 346,639 & $45.5 \%$ \\
\hline Source: Nati & $5,5 \%$ & &
\end{tabular}

Source: National Statistical Service of Greece, 2001 Census

According to the 2001 Census, the majority of immigrants came to Greece looking for a job (58.9\% of males and $48.6 \%$ of females $)^{9}$ and this is probably the reason that more than $80 \%$ are between 15 and 64 years of age; thus, potentially economically active individuals. The second most common reason for immigrating to

9 A very different conclusion is drawn by Kontis et al. (2006) who, using 2003/4 data from residence, report that $82.5 \%$ of immigrants came to Greece to work. 
Greece is family reunion ${ }^{10}$ (approximately 13\%) and repatriation ${ }^{11}$ (almost $7 \%$ ). Nevertheless, over a fifth $(21.5 \%)$ did not specify the reason for immigrating. ${ }^{12}$

According to the 2001 Census, nearly $50 \%$ of immigrants have secondary education certificates (including technical schools) and 33\% either completed or only attended some years of primary school. Almost $10 \%$ have tertiary education degrees - the percentage is higher among females. ${ }^{13}$ Albanians had the lowest educational qualifications, while former Soviet citizens had the highest ones. As far as occupational characteristics are concerned, over $90 \%$ of immigrants are employees, while $6.5 \%$ appear to be self-employed (2.8\% are employers). This is not surprising considering the fact that most immigrants do not speak Greek fluently, at least at the beginning, which is often a necessary prerequisite for self-employment. ${ }^{14}$

According to Robolis (2005), $13.0 \%$ of all employees in Greece are immigrants, while according to the Labour Force Surveys they have increased their share in the labour force from 3.7\% in 1998 to almost 7.0\% in 2004 (Kontis et al., 2006). Most of the jobs performed by immigrants are low-skilled, involving manual work, well below their level of education and typical qualifications. ${ }^{15}$ Almost 25\% of immigrants are employed in construction, which means that $27.4 \%$ of all workers employed in this

10 Cavounidis (2003) argues that female immigrants more often leave their spouse and children behind in the country of origin and, therefore, they may prove the main initiators of migration for family reunification in the future..

11 Of those who reported repatriation as the main reason for immigrating, more than 15,000 are immigrants from western countries (US, Australia, Canada and Germany), which is in line with our speculation concerning immigrants from developed countries.

12 Another reason for immigrating is asylum seeking. According to Gropas \& Triandafyllidou (2005b) the percentage of asylum seekers accepted to Greece rose slightly between 1997 and 2001. The absolute numbers are small, though. For example, in 2001 there were 5,499 applications (295 granted) compared to 4,376 in 1997 (224 granted).

13 Data from 2004/5 HBS reveal a worrying pattern since young immigrants' percentages in upper secondary and tertiary education (students) are substantially lower (33.0\% and $14.5 \%$, respectively, of relevant age groups) than natives' percentages (Kontis et al., 2006).

14 Furthermore, in many cases it is imperative for a self-employed person to register to a professional chamber, in order to get a license to work, which is an additional barrier.

15 This phenomenon is usually referred to as over-education. Lianos (2003) investigates the extend of over-education in the Greek labour market amongst tertiary education graduates -including immigrants- and concludes that there is indeed over-education and that it is twice as common among immigrants than among Greeks (66.1\% as opposed to $37.0 \%)$. Further, he reports that over-education is more frequently observed among Greek males and immigrant females. As a solution to the problem, Lianos (2004b) recommends, firstly, policies aimed to help immigrants improve their command of Greek language and, secondly, policies aimed to limit the list of regulated professions and change the practises of the corresponding professional associations. 
sector are not Greek. Further, 20\% of immigrants are employed in other services, in most cases domestic labour (taking care of children or elderly persons, house cleaning, etc.), which amounts to $75 \%$ of total employment in domestic services. On the other hand, $17.5 \%$ of immigrants are employed in the agricultural sector $(11.6 \%$ of agricultural employment) and a little more than $15 \%$ in tourism and trade.

Apart from immigrant citizens of third countries, there are many foreigners who are virtually - but not typically - considered immigrants. Those are immigrants of Greek descent who repatriated from former Soviet Republics during the 1990s. ${ }^{16}$ According to a special Census conducted by the General Secretariat of Emigrant Greeks (GSEG), at the beginning of 2000 there were 152,204 immigrants of Greek descent residing in Greece, of whom 80,000 came from Georgia, 31,000 from Kazakhstan, 23,000 from Russia and approximately 9,000 from Armenia. The exact number of Albanians of Greek descent who were naturalised before 2001 and, thus, were not reported as foreigners in either the Census or the GSEG is still not clear. It is estimated, though, that almost 100,000 Albanians of Greek descent reside in Greece and have a special identification card issued at local police stations.

\section{The economic impact of immigration}

The studies examining the economic effects of immigration in Greece are limited in number and depth, at least compared to other European countries and, especially, the US. This is primarily due to the aforementioned lack of the necessary statistical information, in part emanating from the illegal status of a considerable proportion of the immigrants. The experience of several countries shows that the arrival of large numbers of immigrants with a considerable proportion of illegal workers among them in a particular country has serious effects on total production (GDP), the size of the informal sector of the economy, the wage rates of both indigenous and immigrant workers, the rate and type of employment and unemployment of the natives, the distribution of income, the pace of technological

16 See Triandafyllidou \& Veikou (2002) for a discussion of laws concerning immigrants of Greek descent (Pontic Greeks and Greek Albanians). The authors support the notion of a hierarchy of Greekness according to which the immigration policy is formed, so as to treat those immigrants differently by either offering them the Greek citizenship immediately (Pontic Greeks) or after a certain period, during which only the right to enter and settle in the country was granted (Greek Albanians). 
growth, the use of public services and the cost incurred by the state, the amount of remittances taken out of the country, the flows of foreign direct investment and, last but not least, the social security and health systems. The existing studies show that Greece is not an exception to this rule.

\subsection{Level and composition of GDP}

It has been estimated that in the early 1990s, when the share of immigrants in the total population was substantially lower than its current level, the net contribution of immigrants to GDP ranged between 1\% (Lianos et al, 1996) and 1.5\% (Sarris \& Zografakis, 1999). Although at first sight these figures seem quite low in comparison with the immigrants' share in the labour force, Lianos (2004b) argues that this is not surprising since the wages of immigrants are much lower than those of Greeks and, therefore, their contribution to the portion of GDP going to labour should be less than their share in the labour force. Further, Chletsos et al (2005) report a positive and statistically significant relationship between the number of immigrants and the growth rate of the local economy and a negative and statistically significant relationship between the number of immigrants and the product of the agricultural sector as a percentage of local GDP. ${ }^{17}$

More recently, Kontis et al. (2006) attempt to estimate the economic impact of immigrants (both legal and illegal) on GDP using three different approaches based on the use of Social Accounting Matrices. ${ }^{18}$ In these matrices immigrants are treated as an independent factor-group whose members participate in the process of production, get paid, distribute their value added to households, which in turn consume, save or make transfer payments within the country or abroad. It is estimated that the contribution of immigrants to GDP in 2004 ranges from $2.3 \%$ (expenditures side) to $2.8 \%$ (income generating side). Between $0.5 \%$ and $0.8 \%$ of these figures is due to the contribution of undocumented immigrants.

17 The latter is attributed to the fact that prefectures, in which agriculture is important, produce less than average output per worker, partly because they rely on labour intensive techniques.

18 This approach is similar to the one adopted by Sarris \& Zografakis (1999). However, in the sample of Kontis et al. (2006) the immigrants accounted for around $10 \%$ of the labour force and most of them were legal (mid-2000s), whereas in the sample of Sarris \& Zografakis (1999) only 3.2\% of the labour force were immigrants and most of them were illegal (mid1990s). 
Immigrants, particularly undocumented ones, are usually employed in the excessively large informal (shadow) sector of the Greek economy, mainly in temporary jobs and are paid wages lower than those of Greek workers with similar qualifications (Lianos et al, 1996; Chletsos \& Karasavoglou, 1997; Markova \& Sarris, 1997; Kontis et al., 2006). According to Lianos et al (1996), Kanellopoulos (2005) and Labrianidis \& Lyberaki (2001) the employment of immigrants in the informal sector of the economy resulted in an expansion of the underground economy. Earlier studies (e.g. Kanellopoulos et al, 1995) estimate that informal economic activities accounted for more than $30 \%$ of GDP in the late 1980s, while between $16 \%$ and $20 \%$ of the labour supplied and employed in Greece was not registered. Hence, it would be unfair to claim that the immigrants are mainly responsible for the large share of informal economy in Greece, since it existed long before they arrived. According to Kanellopoulos (2005), other factors seem to be more influential in maintaining the extensive informal economy in Greece, such as the high level of social insurance contributions, the socially unfair distribution of public benefits, labour market rigidities and the weakness of public administration.

\subsection{Wages and unemployment}

As far as wages are concerned, Lianos et al (1996) using data from a number of Northern Greece prefectures calculated productivity (lower for immigrants according to Table 2) and wages (also lower for immigrants according to Table 3) for legal (documented) and illegal (undocumented) immigrants and native workers with comparable skills. Immigrants' wages adjusted for productivity appear to be lower than those of Greek workers with similar qualifications. This is probably the most important reason why employers seem to prefer immigrants to Greeks, assuming they have the choice. Other reasons could be the flexibility of immigrants in performing different jobs and their higher degree of geographical mobility in comparison with native workers (Fakiolas, 1999). Lower immigrants' wages are not necessarily due to lower qualifications. They could be caused by discrimination against them in the labour market. Demoussis et al. (2006) investigate the issue and conclude that $48 \%$ of the wage differential between natives and immigrants is due to discrimination, but when occupational segregation is taken into account, it turns out that almost $90 \%$ of that component can be attributed to between-occupations differences. Therefore, the major cause of observed wage differentials seems to be the 
asymmetrical occupational access of natives and immigrants (segregation), rather than their unequal treatment within a given occupation.

Table 2 - Productivity levels of legal and illegal immigrants compared to those of similarly skilled Greeks

\begin{tabular}{lcccrrrrr}
\hline \multirow{2}{*}{ Prefecture } & \multicolumn{2}{c}{ Same or higher } & \multicolumn{2}{c}{$\begin{array}{c}\text { Lower } \\
\text { by } 0-20 \%\end{array}$} & \multicolumn{2}{c}{$\begin{array}{c}\text { Lower } \\
\text { by } 20-40 \%\end{array}$} & \multicolumn{2}{c}{$\begin{array}{c}\text { Lower by more } \\
\text { than } 40 \%\end{array}$} \\
\cline { 2 - 9 } & Legal & Illegal & Legal & Illegal & Legal & Illegal & Legal & Illegal \\
\hline Thessaloniki & 33.3 & 16.7 & 66.7 & 0.0 & 0.0 & 50.0 & 0.0 & 33.3 \\
Pella & 25.0 & 33.3 & 25.0 & 8.3 & 41.7 & 33.3 & 8.3 & 25.0 \\
Imathia & 26.3 & 20.0 & 52.6 & 30.0 & 21.0 & 45.0 & 0.0 & 5.0 \\
Kilkis & 18.8 & 29.4 & 37.5 & 17.6 & 25.0 & 29.4 & 18.8 & 47.1 \\
Total & 24.5 & 21.8 & 43.4 & 18.2 & 24.5 & 34.5 & 7.5 & 25.2 \\
\hline
\end{tabular}

Source: Lianos et al (1996), CIDER Survey Phase I

Perhaps, the most important question is whether the influx of immigrant workers caused wages of Greek workers to fall and, if so, to what extend. Lianos (2004b) argues that, although real wages did not decline during the 1990s, they appear to have increased at a lower rate than in the past. Interestingly, minimum nominal wages rose by $1 \%$ to $2 \%$ yearly, while the increase on average wages was higher. This result is in line with the findings of Sarris \& Zografakis (1999) and Kontis et al (2006). A plausible explanation could be that minimum wage workers are unskilled, perhaps with limited work experience, and, consequently, they are the ones competing with immigrants. Therefore, it can be argued that the wages of unskilled and medium-skilled Greek workers are likely to have been compressed by

Table 3 - Wages for various categories of workers as reported by farmers

\begin{tabular}{lcccccc}
\hline & \multicolumn{2}{c}{ Wages } & \multicolumn{2}{c}{$\begin{array}{c}\text { Social security } \\
\text { contributions }\end{array}$} & \multicolumn{2}{c}{ Payments in kind } \\
\cline { 2 - 6 } & Daily & Monthly & Daily & Monthly & Daily & Monthly \\
\hline Perm. skilled Greek workers & 5.0 & 153.0 & 1.8 & 52.0 & - & 10.0 \\
Perm. unskilled Greek workers & 4.3 & 112.3 & 1.5 & - & 1.0 & - \\
Legal skilled immigrants & 4.6 & 137.5 & 1.2 & 30.0 & 1.5 & 45.0 \\
Legal unskilled immigrants & - & 109.5 & - & - & 2.0 & 62.5 \\
Illegal skilled immigrants & 2.5 & 99.2 & - & - & 1.5 & 40.0 \\
Illegal unskilled immigrants & 3.5 & 125.0 & - & - & 1.1 & 45.0 \\
\hline
\end{tabular}

Source: Lianos et al (1996), CIDER Survey Phase I 
the presence of immigrants. ${ }^{19}$

Ceteris paribus, lower wages led to lower production cost and, thus, weak inflationary pressures at a time when Greece was struggling to enter the European Monetary Union (EMU). Some authors go even further and accuse the Greek state of deliberately sustaining the illegal status of immigrants, in order to benefit from them in the above way. Baldwin-Edwards (2004b) goes as far as claiming that, while Greek citizens wanted the legalisation of immigrants, the Greek state preferred them to be in an illegal or semi-legal status and, thus, be easily controlled and manipulated or even deported, if necessary. In this framework, Lazaridis \& Poyago-Theotoky (1999) developed a simple game-theoretic model in order to determine the optimal policy for the government with respect to the regularisation of undocumented immigrants. The optimal strategy of the government appears to depend on the relative magnitude of employer and government payoffs as well as the size of the fine in case of being caught breaking the law.

Another very important question is related to the impact of immigrants on the rate of unemployment of the native workers. Two conflicting views can be found in the literature. If, on the one hand, foreign and local labourers are substitutes ("substitution hypothesis"), then, since the former are much cheaper to employ than the latter, they would be preferred to them and, thereupon, lead to increased unemployment of the natives. If, on the other hand, foreign workers are complementary to the natives ("segregation hypothesis"), then their increased employment might lead to increased employment of the natives too. The latter is in accordance with the view that immigrants are employed in jobs the natives are not interested in.

Despite the fact that the idea that immigrants replace natives and, thus, increase unemployment among the latter is widely spread among the general public, Fakiolas \& King (1996), Iosifidis \& King (1998) and Fakiolas (1999) argue that this is not the case for Greece, since immigrants are usually employed in jobs that the natives turn down. Likewise, Hatziprokopiou (2005) argues that immigrants are typically employed in manual jobs in the construction or manufacturing sector (including small workshops) or jobs at the bottom-end of the service sector ladder

19 Further, Kontis et al. (2006) point out that the arrival of new immigrants most probably has negative effects on the wages of old immigrants, since these two groups of workers are likely to be close substitutes. 
(e.g. retail trade, cafes and restaurants, domestic services), which are physically demanding and unskilled employees are preferred. In addition, based on a survey conducted by him, he finds that small and medium size firms, in most cases family owned, as well as individuals or households are the potential employers of immigrants.

Using more elaborate techniques, Lianos et al (1996) estimate that immigrants, both legal and undocumented, substitute for Greek workers $(0.5 \%$ and $5.8 \%$ respectively), particularly in the unskilled labour market, especially in agriculture and construction where immigrants are a significant percentage of the employed workforce. Nevertheless, they also argue that Greek workers would not have performed many such jobs at all, especially in agriculture and construction. Sarris \& Zografakis (1999) also report, that about one third of undocumented immigrant workers are net displacement of the Greeks, while the rest of them are net addition. The displacement occurs, because immigrants increase the labour supply of the unskilled and compress real wages, which fall just enough to drive native workers out of the labour force. Furthermore, they argue that due to complementarities, the influx of immigrants is associated with increases in the real wages of skilled labour and, along with it, increases in total supply and employment of skilled labour.

According to Cavounidis (1998) there is a shift from family labour to wage labour due to immigrants, because activities previously performed by family members, mainly in the agricultural sector, small firms and domestic services, are now performed by hired immigrants. It is not clear, though, whether the natives that were substituted by foreigners found other jobs or dropped out of the labour market. Cavounidis (2006) re-examines the phenomenon and confirms its occurrence, while she argues that the structure of employment in Greece (large share of self-employed and family workers compared to other European countries) converges to European standards due to immigrants. She reports that in 1986 only $49.3 \%$ of those working where paid employees, while the percentage rose to $63.4 \%$ in 2004 . A substantial proportion of the decline is attributed to the decline in the share of the self-employed in the agricultural sector. The change of family division of labour on and off the farm due to immigrants is also confirmed by Kassimis (2005), who studies the impact of immigrant labour in the agricultural sector in three rural regions in Greece (Ioannina, 
Corinthia and Chania). Further, Labrianidis \& Lyberaki (2001), using a survey carried out by them in Thessaloniki, support the view that more jobs for the natives are created than destroyed by immigrants; thus the two types of labour force are primarily complementary.

Lianos (2003) using data from Labour Force Surveys and the Organisation of Labour Force Employment (OAED) reports considerable differences between natives and immigrants in their employment characteristics. During the period 1998-2001 the rate of employment for Greek males declined by 3.6\%, while it rose for Greek females by $1.3 \%$ and all immigrants (by $16.9 \%$ for males and $8.1 \%$ for females). In addition, the employment rate is higher for immigrants (86\% compared to $60 \%$ for males and $55 \%$ compared to $37 \%$ for females). The same is true for the unemployment rate (7.7\% vs. $6.7 \%$ for males and $17.4 \%$ vs.15.3\% for females); a finding confirmed by Chletsos et al (2005). Further, using both OLS and simultaneous equations techniques, Lianos (2003) concludes that the presence of immigrants affects neither the participation nor the unemployment rate of male native workers. In contrast, it seems that the female employment rate is positively affected by the number of immigrants. One explanation suggested is that the influx of immigrants caused the demand for goods and services to rise, which led to a subsequent increase in the derived demand for labour in Greek firms. The fact that the majority of Greek firms are small and medium sized and mainly family owned coupled with the low participation rates of females resulted in women being hired instead of immigrants on account of their alleged willingness to work part-time, full-time or periodically, without the legal and administrative problems of hiring, firing and paying social security contributions. An alternative explanation may be supply-driven and related to the increased willingness of females to participate in the labour market due to the existence of cheap immigrant labour for domestic services. Either way, as Lianos (2004b) puts it, it could be concluded that immigration did not contribute to increased unemployment in Greece, but led some women to enter the labour market and caused a shift from family to wage labour in certain sectors of economic activity.

The economic impact of immigrants with special reference to the agricultural sector is examined by Chletsos et al (2005) using data from two population surveys (1991 and 2001) and a number of Labour Force Surveys (quarterly data from 1998 to 2003). Their results suggest that, on average, immigrants prefer urban centres (where 
they are employed in construction and domestic services) to the countryside and they seem to choose their place of residence based on the prefecture's GDP and unemployment rate. Interestingly, the unemployment rate of immigrants is directly and positively related to the unemployment rate of the locals, which implies complementary labour forces. More importantly, they conclude that there is neither substitution of Greeks by immigrant workers in the agricultural sector nor is there a significant impact of immigrants on agricultural production. On the other hand, immigrants seem to have a positive impact on the output of the tertiary sector, probably because women immigrants are widely employed in domestic services.

\subsection{Distribution of income}

Directly related to the effects of immigration on unemployment, employment and wage rates is their impact on the distribution of income. As noted above, if immigrants compete with unskilled and medium-skilled native workers, they may end up compressing their wages. On the other hand, if immigrants are considered complementary to skilled workers and capital (mostly in small firms), they may contribute to the increase in their returns. According to Fakiolas (1999) and Glytsos (2005) this is one of the positive effects of immigrants, since they have helped widening what they consider to be an artificially narrow wage differential between unskilled and skilled labour -maintained since the late 1970s by trade union pressures and minimum wage legislation- and, therefore, they have contributed to higher economic efficiency. Thus, they conclude that immigration is likely to have led to increases in income inequality in general and earnings inequality in particular.

The only relevant detailed empirical study in the field is Sarris \& Zografakis (1999) who use a computable general equilibrium (CGE) model of the Greek economy, calibrated to a 1998 Social Accounting Matrix (SAM). There are fifteen classes of households distinguished by skill level or function of the household head and by income-expenditure level. Table 4 presents the most important of their results. They conclude that the influx of immigrants, although macro-economically beneficial, has adverse distributional effects when flexible wage adjustment is assumed in various labour markets. Households in the urban sector headed by unskilled workers are severely hurt by the inflow of immigrants, especially the undocumented ones, and among those especially the households that are initially either poor or middle income. It is interesting to note that all agricultural households, 
irrespective of income level, benefit from immigration. In addition, households headed by skilled workers or economically inactive individuals, such as pensioners, also seem to benefit from the presence of undocumented immigrants. In summarising, it is estimated that approximately $37 \%$ of the population - mostly living in poor and middle income households headed by unskilled workers - is hurt by immigration, while the rest of the population, located mainly around the middle and the top of the income distribution benefit from it. If, on the other hand, nominal wages are assumed fixed for salaried workers, then these same households that previously appeared to lose now seem to gain, at least in so far as they manage to keep their jobs. Most of these results are confirmed in a more recent study by Kontis et al. (2006), who follow the same methodological approach using 2004 as reference year and conclude that immigration affects adversely the distribution of income.

Table 4 - Impact of undocumented immigrants on the real disposable income of Greek households

\begin{tabular}{|c|c|c|c|c|c|c|c|}
\hline & \multirow{2}{*}{$\begin{array}{c}\text { Reference } \\
\text { value } \\
\text { (bn. drs) }\end{array}$} & \multicolumn{6}{|c|}{ Deviation from reference (\%) } \\
\hline & & $\begin{array}{c}\text { Basic } \\
\text { scenario }\end{array}$ & $\begin{array}{c}\text { Scenario } \\
1\end{array}$ & $\begin{array}{c}\text { Scenario } \\
2\end{array}$ & $\begin{array}{c}\text { Scenario } \\
3\end{array}$ & $\begin{array}{c}\text { Scenario } \\
4\end{array}$ & $\begin{array}{c}\text { Scenario } \\
5\end{array}$ \\
\hline All households & 8501.6 & 1.08 & 1.25 & 1.01 & 1.97 & 1.74 & 1.28 \\
\hline Poor & 764.8 & -2.60 & -0.13 & 0.25 & 0.80 & -0.08 & 4.97 \\
\hline Middle income & 6167.1 & 0.72 & 0.89 & 0.63 & 1.40 & 1.22 & 0.77 \\
\hline Rich & 1569.6 & 4.30 & 3.33 & 2.85 & 4.80 & 4.66 & 1.52 \\
\hline Agricultural & 980.1 & 1.74 & 2.41 & 2.31 & 4.19 & 3.55 & 4.47 \\
\hline Urban & 4882.6 & 0.23 & 0.57 & 0.10 & 0.94 & 0.75 & 0.51 \\
\hline Unskilled & 2369.5 & -5.78 & -3.89 & -2.05 & -5.44 & -5.54 & 0.55 \\
\hline Semi-skilled & 1345.5 & 6.05 & 4.72 & 2.29 & 6.82 & 6.62 & 0.43 \\
\hline Skilled & 1167.6 & 5.74 & 4.85 & 1.94 & 7.11 & 6.75 & 0.53 \\
\hline Working & 5862.7 & 0.48 & 0.88 & 0.47 & 1.48 & 1.22 & 1.17 \\
\hline Non-working & 2638.8 & 2.41 & 2.07 & 2.20 & 3.06 & 2.89 & 1.53 \\
\hline
\end{tabular}

Source: Sarris \& Zografakis (1999)

\subsection{Production and productivity}

As noted earlier, empirical studies show that immigrants in Greece are paid less than native workers, they work under difficult and often hazardous conditions 
and are mainly employed by small firms - primarily in agriculture and construction and households for domestic services. Immigration is a very important source of labour in these sectors. In fact, Fakiolas \& King (1996) and Fakiolas (1999) go as far as suggesting that many firms would have been shut down - had it not been for immigrants - with negative effects on employment and production. More recent studies (Fakiolas, 2000; Lyberaki \& Pelagidis, 2000; Labrianidis \& Lyberaki, 2001) broadly agree with the view that immigrants helped small and medium size firms survive and, in some cases, increase their competitiveness and profits. Kassimis (2005) focuses on the agricultural sector and argues that immigrants supported both the survival and the expansion of farms, although he also concludes that their impact was more significant in larger farms. In contrast, Lianos (2004a) notes that this effect, although important, may be positive only in the short-run. He argues that in the long-run the use of cheap immigrant labour may delay the adoption of new technology and the substitution of labour with capital in all sectors of economic activity. Thus, in a world where competitiveness and increased productivity require the introduction of new technology and methods of production that rely heavily on capital, it is possible for a country to fall behind due to its attachment to cheap labour and labour intensive production techniques. Undocumented immigrants allow small firms to survive and, therefore, preserve an inefficient industrial structure that cannot be sustained within the European Union in the long run. ${ }^{20}$

\subsection{Budgetary issues}

Given that Greece's fiscal condition is characterised by a very large public debt and continuous budget deficits, it is important to address the issue of the burden put on public services by immigration. Public services include public schools, hospitals, police, administration, transportation etc, the cost of which is directly although not proportionally - related to the size of the population. Empirical evidence (Lianos et al 1996) suggests, though, that the situation may be different in Greece, since the burden put on public services by immigrants is not that significant. This is possibly due to the fact that many undocumented immigrants are seasonal workers who travel without their families or they are afraid of being located and deported and, therefore, do not enrol their children to school or avoid using public

20 The same point is also made in a slightly different context by Labrianidis \& Lyberaki (2001). 
services. The view that immigrants do not overburden the public services in Greece is also supported by Tapinos (2000), although he also claims that the corresponding burden is not inconsiderable in the case of public education. Since the data used in these studies are rather dated, it is not unlikely that the current situation might be different.

Regarding the use of public health services, the evidence is non clear-cut. Immigrants are younger than natives and, hence, have lower needs for health services. Maratou-Alipranti \& Gazon (2005) refer to a pilot survey conducted in a general hospital in Athens, which showed that $6.5 \%$ of patients were immigrants. Health care services are more systematically used by immigrant women compared to men, probably due to childbirth and more frequent gynaecological problems, while few immigrants provide a certificate of poverty to get free treatment. Likewise, using the information of the 2004/5 Household Budget Survey, Kontis et al. (2006) report that the percentage of immigrants hospitalised is a little lower than that of natives $(6.1 \%$ vs. $7.5 \%)$, while natives tend to spend more days in hospital, probably due the different age composition of the two groups. Based on data from IKA, MaratouAlipranti \& Gazon (2005) report that, due to the nature of their (more hazardous) occupations, immigrants are more than twice as likely as natives to suffer an accident at work and, therefore, to need medical treatment.

Unlike undocumented immigrants, legally employed ones contribute to social security funds and pay taxes, thereupon paying for their share of health care services and social infrastructure (e.g. schools and urban transportation). Undocumented immigrants, on the other hand, are only subject to indirect taxation (value added taxes and excise duties). According to Kanellopoulos (2005), though, very few legal immigrants pay income tax, because of their low income, while the income of undocumented ones is even lower than that of legal immigrants. Therefore, he concludes that only a very small proportion of income taxes are lost due to undocumented immigrants and, consequently, the most important negative effect on public revenues is the loss of social security contributions. Using a number of assumptions, Kanellopoulos estimates that this loss amounts to $10 \%$ to $20 \%$ of the contributions paid by legal immigrants.

While adult immigrants, either legal or undocumented, do not usually attend public schools, their children are allowed to and often do. Using data from Labour 
Force Surveys, Kanellopoulos (2005) estimates that over 95\% of immigrants' children attend public schools or, put differently, foreign students amount to $1 \%$ of Greek students. Should a constant per pupil education cost is assumed, then the author concludes that $1 \%$ of educational public expenses in Greece could be attributed to immigrants' children. It is likely that in recent years this percentage has risen as increasing numbers of immigrants bring their families to Greece.

Perhaps the most important burden put on public services by immigrants is associated to public order. For example, according to Kanellopoulos (2005) there are 58 police departments employing 5,000 bushrangers specialising in border control. In addition, tracing illegal immigrants is the main duty of a large number of policemen stationed in these departments. In order to safeguard the Greek coasts from illegal entry of foreigners, the Ministry of Merchant Marine employed in 2003 6,251 persons with 4 choppers, 319 terrestrial vehicles, approximately 200 picket boats and 7 planes. ${ }^{21} \mathrm{~A}$ complete picture of the cost incurred should also include the amount of money spent on detention rooms and expulsions. Although the author concludes that there is no statistical information available to calculate the total cost, he speculates that it should be quite significant.

A relevant study by Lianos \& Benos (2003) estimates the cost of immigrants in terms of increased criminal activity, which requires more funds directed towards fighting crime. Using data provided by the Greek police (1981-2001 for Greeks and 1988-2001 for immigrants) they estimate an upper and a lower bound of the cost incurred by the Greek state by employing two alternative estimation methods.22 According to them, the cost of increased criminal activity by immigrants -including police, judicial and penitentiary services- ranges from 77 million euros to 354 million euros in 2001 (1995 prices). For the whole period of 1996-2001 the cost estimate is between 384 million euros and 1317.6 million euros (1995 prices). In any case, these figures are far from trivial.

21 Naturally, these resources are also employed for other purposes but, undoubtedly, one of their main uses concerns the safeguarding of the Greek coasts from the entry of illegal immigrants.

22 The upper bound is estimated under the assumption that all additional expenses for public order are attributed to immigrants, because the data show an inter-temporal decrease in crimes committed by Greeks. The lower bound is calculated by attributing additional expenses for public order to Greeks and immigrants according to their share of crimes committed. 


\subsection{Remittances}

Among other things, the benefits from immigration of the labour sending country (country of origin) include the reduction of social tensions from unemployment and/or underemployment, the acquisitions of skills in the foreign countries by the returning migrants and the money transfers from migrants to their families back home, i.e. remittances. Markova \& Sarris (1997) using data from a small sample of Bulgarian immigrants in Athens, report that $80 \%$ of them exhibited strong remittance behaviour. According to Table 5, approximately $60 \%$ of them sent more than $50 \%$ of their income to their home country, mostly to their parents and their children.

Table 5 - Share of earnings remitted by immigrants (\%)

\begin{tabular}{lccccccc}
\hline & $0-10 \%$ & $10-20 \%$ & $20-30 \%$ & $30-40 \%$ & $40-50 \%$ & $>50 \%$ & Total \\
\hline AGE & & & & & & & \\
$20-30$ & 0 & 1 & 3 & 2 & 4 & 6 & 16 \\
$30-40$ & 0 & 3 & 0 & 1 & 6 & 16 & 26 \\
$40-50$ & 1 & 2 & 3 & 0 & 3 & 26 & 35 \\
$>50$ & 0 & 0 & 0 & 1 & 0 & 12 & 13 \\
SEX & & & & & & & \\
Male & 0 & 3 & 3 & 2 & 3 & 9 & 20 \\
Female & 1 & 3 & 3 & 2 & 10 & 51 & 70 \\
TOTAL & 1 & 6 & 6 & 4 & 13 & 60 & 90 \\
\hline
\end{tabular}

Source: Markova \& Sarris (1997)

More recent evidence provided by Lianos \& Cavounidis (2006) - using survey data collected from those who had been granted a green card during the first regularization program - show that immigrants in Greece remit on average around a quarter of their income, but the proportion of income remitted differs substantially among immigrants from different countries. Albanians tend to remit less compared to others $(42.4 \%$ vs. $66.8 \%)$ and a higher percentage of those coming from non exsocialist countries tend to remit $(69.6 \%$ vs. $50.3 \%$ - Table 6). Further, Albanian immigrants remit less than $20 \%$ of their income, while the average for the rest of the immigrants is over $30 \% .{ }^{23}$ There is also a difference between men and women in

23 The low percentage of income remitted in the case of Albanians is probably due to the family composition of their migration, since most of them migrate together with their spouse and children (Cavounidis, 2003 and 2004). 
terms of the amounts remitted. Men remit on average $22 \%$ of their income, while the corresponding figure for women is $35 \%$. The propensity to remit is not constant and seems to be negatively correlated with the length of stay. For instance, there is evidence that those who have lived more than five years in Greece remit 22\% of their income, while the corresponding figure for those who have lived in the country for less than five years is $30 \%$. On the other hand, the elasticity of remitting is less than one, which means that the percentage change of remittances is always lower than the percentage change of income.

Table 6 - Share of immigrants that remit

\begin{tabular}{lccc}
\hline & $\begin{array}{c}\text { Number of } \\
\text { immigrants }\end{array}$ & $\begin{array}{c}\text { Number of } \\
\text { immigrants } \\
\text { that remit }\end{array}$ & Ratio (\%) \\
\hline 1. Total & 899 & 475 & 52.8 \\
2. Males & 692 & 335 & 48.4 \\
3. Females & 207 & 140 & 67.6 \\
4. Albanians & 516 & 219 & 42.4 \\
5. Non Albanians & 383 & 256 & 66.8 \\
6. Former Socialist countries & 708 & 356 & 50.3 \\
7. Non socialist & 115 & 80 & 69.6 \\
8. Less than 2 years in Greece & 16 & 8 & 50.0 \\
9. More than 2 years in Greece & 861 & 451 & 52.4 \\
10. Less than 5 years in Greece & 303 & 206 & 68.0 \\
11. More than 5 years in Greece & 596 & 299 & 50.2 \\
\hline
\end{tabular}

Source: Lianos \& Cavounidis (2006)

Further, Lianos \& Cavounidis (2004) investigate the factors that determine the probability to remit and the amount of remittance. They conclude that the decision to remit depends on the migrants family situation (number of children, existence of a spouse, parents and whether they are in Greece), while the size of the remittances depends on the level of income, the total number of children and the number of children in Greece. Immigrants from less deprived families are more likely to send money home, while those with steady jobs remit less money than those employed in less secure jobs. In a recent work, Lianos \& Cavounidis (2008) examine the role of two additional factors affecting remittances, namely stability of employment and relative deprivation. They conclude that employment stability has no significant effect on the decision to remit, but those immigrants in steady jobs remit less money. 
On the other hand, immigrants coming from less deprived families are more likely to send money back home, but the size of those remittances does not depend on their family's economic conditions. ${ }^{24}$

Remittances are crucial for the receiving countries, because they raise disposable incomes and consumption and provide foreign exchange necessary for the import of raw materials and capital goods, which are an imperative prerequisite for economic development. On the other hand, remittances reduce disposable income and aggregate demand in the host-country. If one takes into consideration that Greece is a member-state of the European Monetary Union (EMU) and, thereupon, has adopted euro as its national currency, it is not difficult to realise that remittances may never return to Greece via exports, tourism etc. and, thus, they are likely to constitute a net loss of national income. This is particularly true for immigrants coming from distant countries like India, Pakistan and Philippines and less so in the case of neighbouring Balkan countries. It is estimated that in 2000 remittances from immigrants in Greece were approximately 509 million euros, of which 219,2 million euros from Albanians alone (Lianos \& Cavounidis, 2006), while Kanellopoulos (2005), based on more recent data, reports that remittances from Albanians in Greece amount to $\$ 400$ million per year.

\subsection{Social security}

The arrival of a considerable number of immigrants in a small country in a short period of time is likely to affect the demographic structure of the country's population. On average, immigrants are younger than natives and, thus, they have contributed to the rejuvenation of the total population. As noted, between 1991 and 2001 Censuses the increase in population is almost exclusively due to immigrant flows. Nevertheless, Bagavos and Papadopoulou (2002) argue that the effect of immigration on the demographic structure of the population was not dramatic. For example, according to their estimates, the share of persons aged over 65 would have been $16.7 \%$ without the immigrants against $15.8 \%$ that is the percentage after immigration. Long-term effects will depend on how many of those immigrants will stay permanently in Greece. In any case, the authors also claim that even if current

24 The explanation provided by the authors is that those from more deprived families prefer to bring their families to Greece and, thus, save money instead of remitting. Further, those without a steady job prefer to remit more in order to account for the probability to stop remitting once unemployed. 
immigrant flows persist in the future, they will still be insufficient to stop the ageing of the population.

Directly related to the impact of immigration on the demographic structure of the country is migration's impact on the social security system. There are only two studies examining the effect of immigrants on the social-insurance system. The first is by Maratou-Alipranti \& Gazon (2005) who use data from the 2001 Census and the 2003 Labour Force Survey as well as information provided by the three largest social insurance funds, namely the social security institution for wage and salary earners (IKA), the social security organisation for self-employed (OAEE) and the social security organisation for farmers (OGA). Based on available data, all legal immigrants pay social security contributions and are, thus, insured. Social security benefits are similar for immigrants and natives but, due to their lower incomes, immigrants pay lower social security contributions (on average, 2,563 euros annually vs. 3,414 euros for Greeks), which - in the long run - will lead to lower pensions.

Due to limited computerisation, all three social security institutions provided insufficient data. Nevertheless, those provided by IKA allow for some general conclusions to be drawn. They suggest that immigrants' contributions amounted to $11.0 \%$ of all IKA contributions in 2003. Immigrants pay higher contributions as a percentage of their earnings (37.8\% vs. $43.1 \%$ - see Table 7 ) probably due to higher contributions paid by workers in hazardous jobs (as well as to the fact that almost none of them are paid wages high enough to reach the social security contributions ceiling that is achieved by a fair number of native workers). Maratou-Alipranti \& Gazon (2005) argue that, from this point of view, the integration of immigrants in the labour market is beneficial in the short-run, because they contribute more than their Greek counterparts. But, in the long-run, they too will retire and will be entitled to pensions. One additional problem will be the low pensions that will be received by immigrants in 20 to 25 years from now, as a result of low social security contributions paid today. The state can either hope that strong family networks will alleviate the problem of elderly poverty or it could organise today a security scheme to aid immigrants with very low pensions. This would be avoided if in the near future many immigrants return to their countries of origin. Even in this case, though, then they will be entitled to pensions (unless they do not have the minimum 
contribution record required), probably through bilateral agreements between Greece and these countries.

Table 7 - Ratio of social security contributions to wages (\%)

\begin{tabular}{lccc}
\hline Nationality & Males & Females & Total \\
\hline Greeks & 37.3 & 38.8 & 37.8 \\
Immigrants & 43.5 & 42.3 & 43.1 \\
Albanians & 45.1 & 44.0 & 44.8 \\
Total (Greeks and Immigrants) & 37.6 & 39.0 & 38.2 \\
\hline
\end{tabular}

Source: Maratou-Alipranti \& Gazon (2005)

The second study attempting to investigate the impact of immigrants on the social security system in Greece is that of Bagavos \& Papadopoulou (2006). They also use data from two Labour Force Surveys (1991 and 2001), two Population Censuses (1991 and 2001) and micro- data from IKA. According to them, there is an intertemporal increase of the labour force in Greece, which is attributed to immigrants and women entering the labour market. They argue that the entry of immigrants has simply postponed the ageing population problem and that their contributions are crucial for the system's survival. They suggest that immigrants will have no effect on the time when the anticipated crisis of IKA will take place (around 2025), because the ratio of natives to immigrants is still very high (thus the effect of immigrants is rather limited), immigrants appear to work shorter periods than natives (reported working time is $20 \%$ shorter for immigrants) and they also receive lower daily wages (by 27\%). In addition, Bagavos \& Papadopoulou (2006) claim that IKA will be in serious trouble in the future, since the balance between pensions and social security contributions for immigrants (as well as natives) is not sustainable. The authors sound even more pessimistic when they point out that if there was a convergence between immigrants and native workers' characteristics and wages, the "judgement day" for IKA would arrive even sooner, due to the expansion of immigrants' rights (see Graph 2). 


\section{Graph 2 - Evolution of reserve funds IKA-ETAM*}

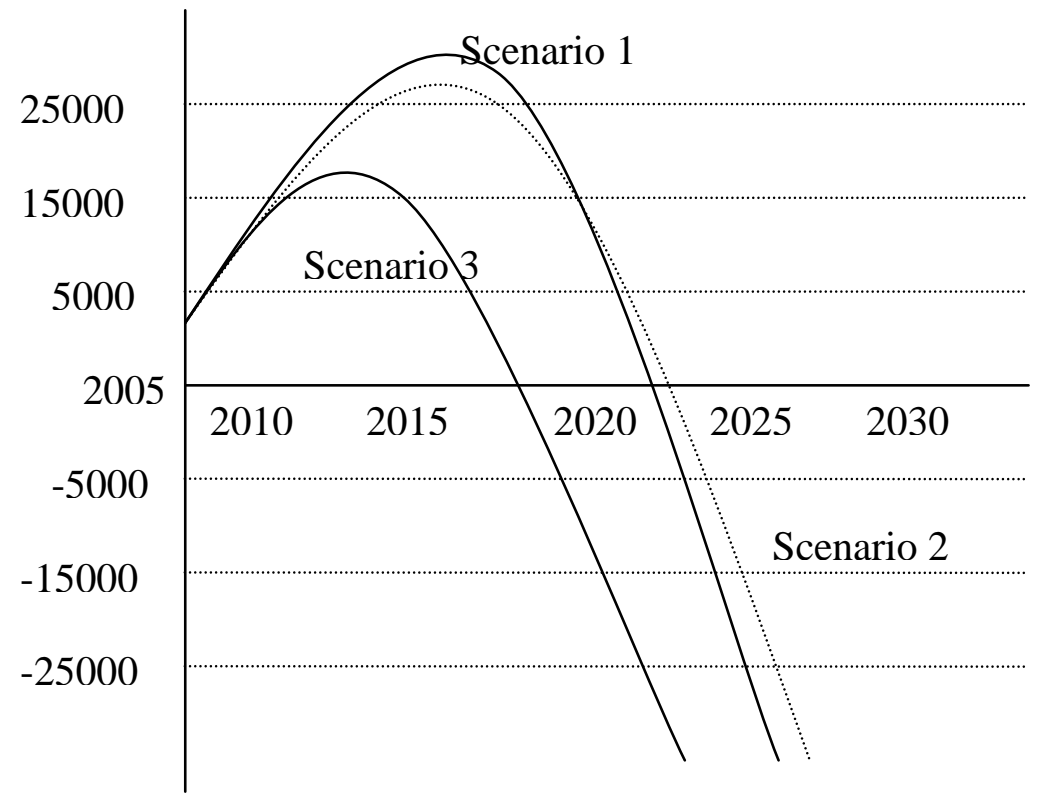

Source: Bagavos \& Papadopoulou (2006)

*Average retirement age is 62 years, GDP growth rate is $3 \%$ and pension increase according to income policy.

Scenario 1: Total number of insured workers, reported working days, reported immigrants' wage.

Scenario 2: No immigrants insured, reported working days, reported wage of Greeks.

Scenario 3: Total number of insured workers, 300 working days, equal wage for immigrants and Greeks.

\subsection{Foreign direct investment}

As Labrianidis et al (2004) point out, in line with the predictions of standard factor mobility models, during the 1990s Greece experienced two distinct trends, which are the two sides of the same coin. On the one hand, there were large inflows of immigrants mostly from neighbouring Balkan countries and, on the other hand, there were large outflows of capital from Greece towards these countries (Petrochilos, 1997, 1999; Salavrakos, 1997; Kekic, 2005). By implication, if labour movement was restricted while capital movement was free, immigration would have been lower and foreign direct investment higher (and vice versa).

It is estimated that in the period 1989-2000 a sum in excess of US\$ 4 billion was invested in these countries by Greek firms, while they also invested significant sums in developed countries too, so that the book value of Greek outward FDI in the turn of the century exceeded US\$ 6 billion (McDonald, 2000). Table 8 shows that by 1999 the largest Greek firms had invested heavily in neighbouring Balkan countries. 
In recent years, this trend accelerated substantially and it is very likely that currently the corresponding figures are considerably higher, while profits earned in these countries boost significantly the balance sheets of the parent companies in Greece. Although a small number of Greek firms account for the bulk of the invested funds, the number of Greek small firms investing in the Balkans is very considerable (especially firms located in regions of the country neighbouring Balkan countries).

Table 8 - Greek investments in the FR Yugoslavia, Romania, Bulgaria, Albania and FYROM, 1999

\begin{tabular}{lrrl}
\hline Company & \multicolumn{2}{c}{ Total Investment } & Sector \\
& USD m. & $\%$ & \\
\hline OTE SA & 1,097 & 45.6 & Telecommunications \\
3E Hellenic Bottling Company & 177 & 7.3 & Beverages \\
DELTA SA & 62 & 2.6 & Food \\
TITAN & 46 & 1.9 & Cement \\
Eurobank & 38 & 1.6 & Banking \\
Mitilinaios Holdings & 32 & 1.3 & Mining \\
Athenian Brewery SA & 28 & 1.2 & Brewery \\
Intracom Group & 26 & 1.1 & Telecommunications \\
Alpha Credit Bank & 21 & 0.9 & Banking \\
Chipita SA & 15 & 0.6 & Food manufacturing \\
Commercial Bank & 13 & 0.5 & Banking \\
Flourmill Loulis SA & 8 & 0.3 & Food manufacturing \\
Flourmills Agiou Georgiou & 8 & 0.3 & Food manufacturing \\
Thrace Papermill & 6 & 0.3 & Paper mill \\
Veropouloi Bros & 6 & 0.3 & Commerce \\
Other companies & 821 & 36.0 & \\
Total & 2,408 & 100.0 & \\
\hline
\end{tabular}

Source: Labrianidis et al (2004)

Salavrakos \& Petrochilos (2003) attempt to investigate the main factors leading to FDI directed from Greece towards the Balkan and Black Sea countries and conclude that the most important are lower wages in the host countries and lower interest rates in Greece after the participation in EMU, which boosted investment. Further, Stoiana \& Filippaios (2008) show that rule of law and high bureaucratic quality are essential for the Greek firms' decision to invest abroad, while the existence of high levels of corruption acts as a deterrent. What is also interesting is that Greek FDI seems to be the result of a strategic business decision, with a long- 
term time horizon, and is systematically spread across numerous countries and sectors of economic activity (Bastian, 2004).

Labrianidis et al (2004) trace the source of this phenomenon as well as the employment of immigrants by small firms in Greece on the effort of small Greek firms to deal with international competition by relying on labour intensive strategies either by using cheap labour supplied by (mainly Balkan) immigrants in Greece, or by exploiting lower labour cost available in the same Balkan countries, thus by investing abroad. They are quite ambivalent regarding the final outcome of this strategy in the sense that these inter-related phenomena can prove either a blessing or a Pandora's Box for the economies and societies of the countries involved. The outcome is likely to depend on social and political factors; for example on their success in building multicultural societies tolerant of differences and on developing attitudes conducive to open economies.

\section{Conclusions}

Greece has experienced a sharp rise in immigration since the early 1990s as a result of social, economic and political changes in former communist countries following the collapse of the Soviet Union. The first immigrants came from Poland, but many others followed them; they were mostly illegal and were mainly looking for a job. The key feature in Greece's experience, though, that made Greece different from other south European countries was the dominance of immigrants from a single country, namely Albania. Greece needed a cheap labour force in order to contain costs and price increases to accommodate her effort to meet the criteria set in order to participate in the European Monetary Union and immigrants, especially the illegal ones, provided it, since they were in no position to negotiate wages or working conditions. They would perform any job, as long as it allowed them to stay in the country, even with bad living conditions or the fear of getting deported, if arrested. Most immigrant males are employed in construction and the agricultural sector, while the majority of women are employed in domestic services.

Under the increasing number of immigrants, the government attempted to introduce a migration policy, which at first was aiming at stopping the immigrants from getting into the country. Due to the geographic location of Greece and the fact 
that most immigrants were coming from neighbouring Balkan countries, these efforts quickly proved inadequate. The next step was to try to legalise them. Three legalisation schemes were put into practice, but bureaucracy and public sector rigidities led to unsatisfactory results. Some commentators go as far as accusing Greece of deliberately creating obstacles, in order to limit the number of immigrants getting a legal work and residence permit, and allow their employers to exploit them. The bottom line is that the categories of immigrants still remain fuzzy and, because of bureaucracy and, especially, lack of administrative will, immigrants continue to fall in and out of legal status.

Although many studies attempt to investigate the impact of immigrants on the Greek economy, the lack of truly reliable statistical information seriously constrains their results. Most of the studies, though, agree that immigrants have positive and negative economic effects. Among the positive effects are mentioned the increase in the GDP growth rate, the revitalisation of the agricultural sector and many small and medium enterprises, at least in the short-run and the dampening of inflationary pressures. On the negative side, immigrants are thought to have helped the expansion of the already large informal economy, in some cases they have substituted Greek unskilled and semi-skilled workers (although according to others, they have freed up the labour force, leading to a better division of labour and higher product per worker) leading to increased income inequality, unemployment and slow growing wages, especially for those with low skills, and contributed to the slowing down of technological developments since firms found it easier to hire cheap labour than to invest in capital intensive production techniques. In some other issues, such as the impact of immigrants on overall employment and unemployment, a definite answer is not clear. Public services do not seem to have been overburdened by the presence of immigrants, with the exception of services related to public order. Due to their low incomes, immigrants pay very little direct taxes, whereas the impact of immigrants on the social security system is considered positive in the short-run, but it is expected to become negative in the long-run.

Undoubtedly, Greece needs to find ways to incorporate immigrants both socially and economically. A more straightforward and clear-cut immigration policy is a sine qua non, in order to simplify and rationalise the process of legalisation for the different groups of immigrants. More attention needs to be paid to the 
immigrants' needs as well as their social, political, religious and human rights. It is also both necessary and important to collect appropriate statistical data that will help researchers get a clearer picture of the situation that will allow better informed and more efficient policies to be planned and implemented by the government and NGOs. Last but not least, attention should be paid and efforts should be made in order to accommodate the integration of second generation immigrants, an issue not yet fully comprehended by the majority of researchers and politicians (Cavounidis, 2006). 


\section{References}

Bagavos, Ch. and D. Papadopoulou. 2002. Trends of Migration and the European Migration Policy. INE-ADEDY Labour Institute Study No.15. (in Greek)

Bagavos, Ch. and D. Papadopoulou. 2006. Immigration and Immigrants' Incorporation to the Greek Society. Scientific Company of Social Policy. (in Greek)

Baldwin-Edwards, M. 2004a. Immigration into Greece, 1990-2003: A Southern European Paradigm? Paper presented at the European Population Forum 2004, Mediterranean Migration Observatory.

Baldwin-Edwards, M. 2004b. Albanian Emigration and the Greek Labour Market: Economic Symbiosis and Social Ambiguity. South-East Europe Review, 1: S51-56.

Baldwin-Edwards, M. 2004c. Statistical Data for Immigrants in Greece: A Thorough Investigation of Available Data and Proposals to Meet European Union Standards. Institute of Migration Policy (IMEPO) and Mediterranean Observatory of Migration final report, Panteion University.

Bastian, J. 2004. 'Knowing your way in the Balkans': Greek foreign direct investment in Southeast Europe. Southeast European and Black Sea Studies, 4(3): 458-490.

Cavounidis, J. 1998. The Immigrant Labour Force in the Informal Economy in Greece. Paper presented at the third international metropolis conference at workshop "Immigrants in Mediterranean Cities: Insertion in an Informal Economy and Society", in Zichron Yaakov, Israel.

Cavounidis, J. 2002a. Migration in Southern Europe and the Case of Greece. International Migration, 40(1): 45-70.

Cavounidis, J. 2002b. Immigrants' Characteristics: The Greek Legalisation Program of 1998. Athens: Sakkoulas. (in Greek)

Cavounidis, J. 2003. Gendered Patterns of Migration to Greece. The Greek Review of Social Research, 110: 221-238.

Cavounidis, J. 2004. Migration to Greek from the Balkans. South Eastern Journal of Economics, 2: 35-59.

Cavounidis, J. 2006. The Labour Market Integration of Migrants in Greece. In Managing Migration: The Greek, EU and International Contexts, ed. D.Papademetriou and J.Cavounidis. Athens: Hellenic Migration Policy Institute (IMEPO).

Cavounidis, J. 2006. Labour Market Impact of Migration: Employment Structures and the Case of Greece. International Migration Review, 40(3): 635-660.

Chletsos, M. and A. Karasavoglou. 1997. The Impacts of Illegal Immigrants on Regional Level-Evidence from Kavala Region in Greece. Paper presented at the Centre for Economic Research Workshop 1997, Athens.

Chletsos, M. et al. 2005. Economic Aspects of Immigration. Effects on the Agricultural Sector. Athens: Hellenic Migration Policy Institute (IMEPO). (in Greek)

Demoussis, M., N. Giannakopoulos and S. Zografakis. 2006. Native-Immigrant Wage Differentials and Occupational Segregation in the Greek Labour Market. University of Patras Economics Department Working Paper No.6.

Fakiolas, R. \& R. King. 1996. Emigration, Return, Immigration: A Review and Evaluation of Greece's Post-war Experience of International Migration. International Journal of 
Population Geography, 2: 171-190.

Fakiolas, R. 1999. Socio-Economic Effects of Immigration in Greece. Journal of European Social Policy, 9(3): 211-229.

Fakiolas, R. 2003. Regularising Undocumented Immigrants in Greece: Procedures and Effects. Journal of Ethnic and Migration Studies, 29(3): 535-561.

Glytsos, N. 2005. Stepping from Illegality to Legality and Advancing towards Integration: The Case of Immigrants in Greece. Athens: KEPE.

Gropas, R. and A. Triandafyllidou. 2005a. Active Civic Participation of Immigrants in Greece. Country Report for the European Research Project POLITIS.

Gropas, R. and A. Triandafyllidou. 2005b. Migration in Greece at a Glance. ELIAMEP.

Hatziprokopiou, P. 2005. Immigrants' Integration and Social Change: Greece as a Multicultural Society. Paper presented at the 2nd LSE Symposium on Modern Greece, Current Social Science Research in Greece, LSE, European Institute, Hellenic Observatory.

Iosifidis, Th. and R. King. 1998. Socio-spatial Dynamics and Exclusion of Three Immigrant Groups in the Athens Conurbation. South European Society and Politics, 3(3): 205-229.

Kanellopoulos, C. 2005. Illegally Resident Third Country Nationals in Greece: State Approaches Towards them, their Profile and Social Situation. Paper prepared for the European Migration Network and KEPE.

Kanellopoulos, C., I. Koussoulakos and B. Rapanos. 1995. Informal Economy and Tax Evasion: Measurements and Economic Effects, KEPE, Study No.15. (in Greek)

Kapsalis, A. and P. Linardos-Rylmon. 2005. The Greek Migration Policy. Report and Suggestions from Trade Unions Point of View. In Migration Policy and Immigrants' Rights, ed. A. Kapsalis and P. Linardos-Rylmon, 11-27. Athens: Labour Institute Study No.22, INE-ADEDY. (in Greek)

Kapsalis, A. 2005. The Right to Stay and Immigrants' Employment. In Migration Policy and Immigrants' Rights, ed. A. Kapsalis and P. Linardos-Rylmon, 55-70. Athens: Labour Institute Study No.22, INE-ADEDY. (in Greek)

Kassimis, Ch. 2005. Migrants in the Rural Economies of Greece and Southern Europe. Agricultural University of Athens Working Paper.

Kassimis, Ch. and Kassimi, Ch. 2004. Greece: A History of Migration. Agricultural Migration Information Source Working Paper.

Katseli, L. and N. Glytsos. 1989. Theoretical and Empirical Determinants of International Labour Mobility: A Greek-German Perspective. In European Factor Mobility: Trends and Consequences, ed. I. Gordon and A.P. Thirlwall. London: MacMillan.

Kekic, L. 2005. Foreign direct investment in the Balkans: recent trends and prospects. Southeast European and Black Sea Studies, 5(2): 171-190.

Kiprianos, Pr., S. Balias and V. Passas. 2003. Greek Policy towards Immigration and Immigrants. Social Policy \& Administration, 37(2): 148-164.

Koniordos, M. 1994. Employment and Greek Educational Policy. In The Protection of the Rights of Migrant Workers and their Families: The International and National Dimension, ed. C. Theodoropoulos and A. Sykiotou, 167-181. Athens: Marangopoulos 
Foundation for Human Right, Publications Estia.

Kontis, A., S. Zografakis and Th. Mitrakos. 2006. The Economic Impact of Employing Immigrants During the Last Decade in GDP. http://www.imepo.gr/documents LepiptoseisAEP.pdf)

Labrianidis, L. and A. Lyberaki. 2001. Albanian Immigrants in Thessaloniki. Thessaloniki: Paratiritis. (in Greek)

Labrianidis, L., A. Lyberaki, P. Tinios and P. Hatziprokopiou. 2004. Inflow of Migrants and Outflow of Investment: Aspects of Interdependence between Greece and the Balkans. Journal of Ethnic and Migration Studies, 30(6): 1-26.

Lazaridis, G. and J. Poyago-Theotoky. 1999. Undocumented Migrants in Greece: Issues of Regularization. International Migration, 37(4): 715-740.

Lianos, T.P. 1975. Flows of Greek Out-Migration and Return Migration. International Migration, 13(3): 112-118.

Lianos, T.P. 1980. Movement of Greek Labour to Germany and Return. Greek Economic Review, 2(1): 71-77.

Lianos, T.P. 1997. Factors Determining Migrant Remittances: The Case of Greece. International Migration Review, 31(1): 72-87.

Lianos, T.P. 2001. Illegal Migrants to Greece and their Choice of Destination. International Migration, 35(2): 3-28.

Lianos, T.P. 2003. Contemporary Immigration in Greece: An Economic Examination. Athens: KEPE Study No.51. (in Greek)

Lianos, T.P 2004a. Brain Drain and Brain Loss: Immigrants to Greece. Unpublished.

Lianos, T.P. 2004b. Report on Immigration to Greece. European Migration Network and KEPE.

Lianos, T.P. \& Benos, Th. 2003. The Criminality of Foreigners. Athens: KEPE Study No.41. (in Greek)

Lianos, T.P. \& Cavounidis, J. 2004. Immigrant Remittances, Stability of Employment and Relative Deprivation. Unpublished. (in Greek)

Lianos, T.P. \& Cavounidis, J. 2006. Propensity of Migrants in Greece to Remit. In Economic Systems, Development Policies and Business Strategies in the Era of Globalisation, ed. V. Angelis and L. Maroudas, 609-622. Athens: Papazisis Publishers. (in Greek)

Lianos, T.P. \& Cavounidis, J. 2008. Immigrant Remittances, Stability of Employment and Relative Deprivation. Forthcoming in International Migration, 46(5).

Lianos, T.P., Sarris, A.H. \& Katseli, L.T. 1996. Illegal Immigration and Local Labour Markets: The Case of Northern Greece. International Migration, 34: 449-484.

Lyberaki, A. and Th. Pelagidis. 2000. The Fear of the Foreigner in the Labour Market: Tolerances and Prejudices in Development, Athens: Polis. (in Greek)

Maratou-Alipranti, L. and E. Gazon. 2005. Immigration and Health-Care. An Evaluation of the Present Situation - Challenges and Prospects of Improvement. EKKE Report.

Markova, E. and A. Sarris. 1997. The Performance of Bulgarian Illegal Immigrants in the Greek Labour Market. South European Society and Politics, 2(2): 57-77. 
McDonald, R., 2000. Breaking out: a survey of the Greek foreign investment. Business File, Greek Special Survey Series No. 37 of Industrial Review (Oikonomiki Viomichaniki Epitheorissi), October.

Petrochilos, G.A., 1997. Theory, policy and practice of Greek outward foreign direct investment. In Business and Economics for the 21st Century, ed. D. Kantarelis, 117127. Anthology of 1997 B.E.S.I. Conference Papers. USA: Worcester, MA 01605.

Petrochilos, G.A., 1999. Explaining Greek outward foreign direct investment: a case of regional economic integration. Economics Research Paper Series. Coventry University, RP9903.

Robolis, S. 2005. Economy, Labour Market and Immigration in Greece. In Migration Policy and Immigrants' Rights, ed. A. Kapsalis and P. Linardos-Rylmon, 29-43. Athens: Labour Institute Study No.22, INE-ADEDY. (in Greek)

Salavrakos, I.D. 1997. The Black Sea Economic Co-operation (BSEC): problems and prospects of integration with the global economy. Occasional Paper No. 10. Institute of International Economic Relations, Athens.

Salavrakos, I.D. and G.A. Petrochilos. 2003. An Assessment of the Greek entrepreneurial activity in the Black Sea area (1989-2000): causes and prospects. Journal of SocioEconomics, 32: 331-349.

Sarris, A.H. and S. Zografakis. 1999. A Computable General Equilibrium Assessment of the Impact of Illegal Immigration on the Greek Economy. Journal of Population Economics, 12: 155-182.

Simopoulos, Ch. 2005. The Relationship of Immigrants with Administration. In Migration Policy and Immigrants' Rights, ed. A. Kapsalis and P. Linardos-Rylmon, 71-78. Athens: Labour Institute Study No.22, INE-ADEDY. (in Greek)

Skordas, A. and N. Sitaropoulos. 2005. Why Greece is not a Safe Country for Refugees. International Journal of Refugee Law, 16: 25-52.

Stoiana, C. and F. Filippaios. 2008. Dunning's eclectic paradigm: A holistic, yet context specific framework for analysing the determinants of outward FDI: Evidence from international Greek investments. International Business Review, 17: 349-367.

Tapinos, G. 2000. Illegal Immigrants and the Labour Market. Brussels: OECD Observer.

Triandafyllidou, A. and M. Veikou. 2002. The Hierarchy of Greekness. Ethnic and National Identity Considerations in Greek Immigration Policy. Ethnicities, 2(2): 189208.

Triandafyllidou, A. 2005. The Greek Migration Policy: Problems and Directions. ELIAMEP.

Triandafyllidou, A. and R. Gropas. 2007. Greek Education Policy and the Challenges of Migration: An Intercultural View of Assimilation. Paper prepared for the EMILIE project, WP3.

Venturini, A. 2004. Postwar Migration to Southern Europe, 1950-2000. An Economic Analysis. Cambridge: Cambridge University Press. 